\title{
Positions and segments of social classes in the Metropolitan Region of Natal in the 1990s
}

\author{
Posições e segmentos de classes sociais \\ na Região Metropolitana de Natal na década de 1990
}

Marconi Gomes da Silva [I]

\begin{abstract}
The 1990s, seen as the second lost decade, presented low productive dynamics and low dynamics of the labor market in Brazil and in the Metropolitan Region of Natal (MRN). On the current paper, it is considered that the job market shows that the social classes are even more segmented. According to this perspective, the paper was based on Santos (2002) to study the segmentation of the labor market as a proxy of positions and segments of social classes in the analyzed reality. The hypothesis which guides the paper is that the possession of material assets, qualification and command positions are crucial to take on better positions in the structure of classes from the distribution standpoint. The analysis of the empirical data allows the increase of trust level in the formulated hypothesis.
\end{abstract}

Keywords: occupational structure; labor market; social classes; social segments; Metropolitan Area of Natal.

\section{Resumo}

A década de 1990, considerada a segunda década perdida, apresentou baixa dinâmica produtiva e do mercado de trabalho no Brasil e na Região Metropolitana de Natal (RMN). No presente artigo, considera-se que o mercado de trabalho apresenta as classes sociais cada vez mais segmentadas. Seguindo essa perspectiva, este trabalho baseou-se em Santos (2002) para estudar a segmentação no mercado de trabalho como proxy das posições e segmentos de classes sociais na realidade estudada. A hipótese norteadora do trabalho é que a posse de ativos materiais assim como qualificação e posições de mando são cruciais para assumir melhores posições na estrutura de classes do ponto de vista da distribuição. A análise dos dados empíricos permite aumentar o grau de confiança na hipótese formulada.

Palavras-chave: estrutura ocupacional; mercado de trabalho; classes sociais; segmentos sociais; Região Metropolitana de Natal. 


\section{Brief theoretical introduction to the topic of social classes in contemporaneity}

There are several studies which have addressed social classes in capitalist societies in the recent period, that is, from the seventies to the end of the second and beginning of the third millennia. Among them, the following can be highlighted: A estrutura de classes das sociedades avançadas (The class structure of advanced societies) (Giddens, 1975); As classes sociais no capitalismo de hoje (The social classes in today's capitalism) (Poulantzas, 1978); A nova classe média (The new middle class) (Mills, 1979); Classe, crise e o Estado (Class, crisis and the State) (Wright, 1981); The debate on classes (Wright, 1989); Class counts (Wright, 1997); Trabalho e capital monopolista (Monopoly capital and labor) (Braverman, 1977); Aspectos da crise social no Brasil dos anos oitenta e noventa (Aspects of social crisis in Brazil in the eighties and nineties) (Quadros, 2003); Espacialização de classes no Brasil (Class spacialization in Brazil) (Maia, 2006).

In spite of the importance of the aforementioned works for the comprehension of social classes in contemporary times, it is highlighted here, as an outcome of the present article, the study by Santos (2002) under the title "Estrutura de posições de classe no Brasil: mapeamento, mudanças e efeitos na renda" (Structure of class positions in Brazil: mapping, changes and effects on income). In this study, Santos (2002) uses as the main reference author Erik Olin Wright, and as an empirical basis, the National Household Sample Surveys (NHSSs) [Pesquisas Nacionais por
Amostra de Domicílios (PNADs)], carried out between 1982 and 1986 by Brazilian Institute of Geography and Statistics (BIGS) [Instituto Brasileiro de Geografia e Estatística (IBGE)] to elaborate a mapping of the social classes structure in Brazil. The idea supported here is that the author was able to reach an excellent approximation of the classes structure in Brazil from the empirical basis already mentioned and, for this reason, the study in question, constituted a fundamental support for the the present article, although its empirical basis is the Demographic Censuses.

At first, it is important to highlight that Santos made several adjustments to the typologies used by Wright, mainly due to the specificities of the sources used. However, this item of the article is not supposed to deal with such changes, but at the heart of the theoretical treatment used by the author. Thus, a brief approximation of Erick $O$. Wright's theoretical elaboration follows, based on the text aimed in the theoretical framework presented by Santos (ibid.).

Although Wright was concerned with the study of all social classes, Wright had to pay special attention to a theme dear to the marxist thought: the middle classes. Given that the middle classes are a controversial subject in marxist literature, it is imperative to highlight that Wright positioned himself in the debate as a defender of the perspective according to which the middle classes are characterized, at first, for representing "'contradictory locations within class relations'”, being the contradictory character of the locations resulting from the sharing of "'relational characteristics of two distinct classes'". The first class map was elaborated taking into consideration the 
processes of domination and subordination within production based on the possession of monetary capital, physical capital and "labor"(*) (ibid., p. 38).

Afterward, Wright started to consider exploitation as the center of his class analysis, the key idea being that "material exploitation is determined by inequalities in the distribution of productive assets" (ibid., p. 38). Therefore, the possession of such assets would tend to generate antagonistic interests, since certain social segments start to enjoy good living conditions at the expense of others. The understanding is that "Productive assets are factors or productive resources that generate income". According to this sense of assets, the idea of exploitation would be, then, applicable both to owners of means of production, as well as to some segments of the middle classes, in relation to producers of social wealth because they hold qualifying assets. It would be, then, the inequality of distribution of these assets, the basis of the "transfers of surplus work" and to the structure of classes and class conflicts. Although he draws attention to the fact that "the diverse dimensions of social inequality cannot be reduced to class inequality", he considers that "class relations play a decisive role in shaping other forms of inequality", such as the case of income inequality, since "class positions shape the way in which others reasons influence income" (ibid., p. 44).

Wright also worked with the idea that in capitalism, in addition to capitalism exploitation, there was room for exploitation that was not exactly capitalist, although it was subordinated to it. Therefore, the idea of "contradictory class locations" gains importance. These locations would be exercised by the members of intermediate posts due to the "existence of organizational assets". He considers the organization an asset because it implies "coordinating decision-making about a complex technical division of labor" (ibid., p. 44). In this context, the role played by managers would be fundamental, due to the participation in the domination relations and the "privileged location of appropriation [...] within the exploitation relations", being that such role "guarantees them the perception of "loyalty incomes'" (ibid., p. 45).

Santos presented two versions of the class typologies developed by Wright, one called "basic" and another "developed". Initially, it alludes the difference between classes and class locations, or class positions. He states: "classes are characterized by their location within the social relations of production (ibid., p. 47), while locations or "occupations represent positions defined within the scope of technical relations of production" (ibid., p. 47), given that "the class locations are always structurally interconnected to class relations", therefore "the notion of class structure designates the organization of a set of relations and class locations" (ibid., p. 50).

The class typology elaborated by Wright regarding capitalist societies had, in the case of the basic version, six class locations, while in the second version developed, it had twelve locations (ibid.). In both cases, the typologies were elaborated "according to differentiated appropriation of assets in means of production, qualification of assets and relation with the exercise of domination within production (characterized before as organizational assets)". Santos states that "the critical part [...] is in the internal divisions among wage earners" (ibid., p. 49). 
For the typology developed is a deepening of the basic typology, the reference will be to the first, as it is broader. The first distinction regarding class positions concerns the control of the means of production. According to this classification criterion, there are, on the one hand, the owners or holders of means of production and, on the other, the non-owners or wage workers. In the case of owners of the means of production or material assets, class positions are: bourgeoisie, small employers and petty bourgeoisie. The fundamental criterion used in the classification is the capital contribution. In the case of the first position, the bourgeoisie, there are those whose capital contribution is sufficiently large to allow them to live exclusively on the work of others. In the case of the second, the capital contribution reaches a magnitude that allows employing people, but still imposes the need to "work". In the third case, it concerns holders of means of production, whose contribution is insufficient to employ people. The class considered intermediate or class with a contradictory position has its class position defined by the criterion of relation with authority. There are six positions in which managers and supervisors are classified. These positions are identified as specialists, qualified and unqualified and, therefore, as a result there are three types for managers and three others for supervisors. The positions of managers and supervisors are characterized by the exercise of some level of authority over workers. However, the distinctive character of such positions is that, if supervisors undertake an authority position over workers, managers are also characterized by exercising authority over subordinate segments and by taking part in strategic decision-making in organizations.
Finally, in the class typology in question, there are segments composed of non-manager specialists, qualified workers and, at the base of the structure, non-qualified workers.

Besides presenting a review of "criticisms of Erik Olin Wright class scheme", Santos also proceeded to a reworking of the typologies of that author, considering the specificities of the sources of which he used and, furthermore, taking into account the specificities of the reality which became the object of his study. In conclusion, it is important to highlight that Santos advocates the relevance of Wright's work, mainly because it is a study focused on "systematic empirical research" and related to theory and typology which "are part of an open and in progress work" (ibid., p. 68). It was based on this assessment that Santos used Erik Olin Wright as a reference author for the study of class positions in Brazil. The same reason is taken into account in relation to the study by Santos (ibid.) for the construction of the typologies of class positions presented in the next item of this study.

\section{Methodologic considerations about the topic of social classes based on Demographic Census}

This part of the study is eminently empirical and lists only employed people, based on microdata from Demographic Census, in the perspective of positions and class segments. It is taken under consideration that the current structure in the workforce is a close representation of what happens in society. 
In coherence with the theoretical orientation of the research, rooted on Marx and Marxist authors, the option was to employ as referential typology the one used by Santos (2000). The author was based on studies developed by Erik Olin Wright in order to organize the data from National Household Sample Surveys (NHSSs) [Pesquisas Nacionais por Amostra de Domicílios (PNADs)] from 1981 and 1996. However, as the study developed at the timewas based on Demographic Census, it was necessary to make use of additional work developed by the National Commission of Classification (Comissão Nacional de Classificação - Concla) - created for monitoring, for definition of usage norms and for standardization of national statistics classification - to enable the systematization of information regarding the year 2000, when the Brazilian Institute of Geography and Statistics [IBGE - Instituto Brasileiro de Geografia e Estatística] applied new classifications for the economic activities and occupations. Consequently, it was necessary to observe whether there was dismissal or hiring of the occupations listed in the Demographic Census of 1991 to promote the distribution of people employed according to class segmentation. ${ }^{1}$

It is a fact that, since birth, people are inserted in social differentiations leading them to integrate different social classes. For that reason, Santos (2002) presented two forms of mapping class positions. One of them included the individual who is active and occupied in the workforce and the other one considered the people of reference in the families. For this research, the choice was only for the positioning of people who are active and occupied in the workforce in the periods indicated by Demographic Censuses.
The leading criterion for locating the people according to position and class segmentation was the control of productive assets, understood as "factors or productive resources which generate income" (ibid., p. 43). In reality, the assets may be defined as factors that make it possible to participate in the production process or services and the acquisition of income generated within a reference period.

The categories that represent the occupational positions, as affirmed by Santos (ibid.) referring to the NHSSs information, regard to the historical ways of work division in capitalist societies. With that observation, the positions of employer, self-employed and employee are regarded as basic positions to build the position typology and class segmentations. In addition to that, what is also considered is the control of assets - capital, organizational, qualification or based on 'simple' labor -, which allow participation in production and services, as well as the income participation.

Based on such criteria, occupational groups listed on the Demographic Censuses in 1991 and 2000 were arranged in twenty class segmentations. It is important to mention that the amount of occupational groups in Demographic Censuses in 1991 and 2000 is 381 and 510, respectively. The position Employer was defined by the control of capital assets which permits them to hire people. The segment Grand employers includes those who possess a great deal of capital, which translates into a vast amount of workers. The segment More capitalized Small employers is made up of employers who have smaller amounts of capital but are able to make a living solely with the labor of others. On the other hand, the 
segment Less capitalized Small employers are those with even smaller capital and often get directly involved in the activities they perform due to the fact that they cannot live exclusively with the labor of others.

The position Self-employed, normally identified as an occupation in the condition of independent due to the vast variety of activities performed, was initially segmented taking into consideration whether the independent owned "qualification assets". The ones who were formally qualified were categorized as Self-employed specialists and the ones with no formal qualifications were initially denominated as Non-specialist selfemployed in rural and urban activities. The first ones were classified as Self-employed in agribusiness due to the fact that they are directly involved in that activity. The urban self-employed were defined according to the "capital addition" they possessed, thus they were classified as Capitalized self-employed and Decapitalized self-employed.

The condition of Worker is for those with the role of employees. It is a very heterogeneous group as far as the factors that concerning the participation in production or providing services and consequently acquisition of income. A small part of employers retains "organizational assets", which allows the use of authority in corporate environment, by delegating to their personnel, or in governmental institutions. Therefore, this group is made up of workers who perform as Directors of the private sector or as Directors of the public sector. It is true that each of these segments is subject to a new segmentation, taken into account the nature of the job and the function executed or also the certified qualification that they hold.
Part of the staff takes part in the production or services, essentially because they have qualifications. Those who have certified qualification, "scarce qualifications" were regarded as Specialist workers (ibid., 95). Another group with 'productive' inclusion based on qualifications is the Qualified workers. However, even not having certified qualifications, they are characterized by constituting a workforce with a higher degree of complexity compared to the segments in activities regarded as less complex.

Manual workers are characterized for the lack of means of production and formal qualification as well as for taking a subaltern role in the power structure of the companies where they work. They constitute a proximity with the proletarian workforce. In this paper, they were classified as Manual workers in agribusiness, Manual workers in industry and Manual workers or in subaltern tasks in services.

Regular non-manual workers perform tasks of elementary nature which do not necessarily require a high educational level, hence in their composition, they have relevant participation of workers involved in regular administrative activities. On the other hand, Regular more graduated non-manual workers are different because of their higher educational level and for the execution of tasks that require more trust and normally they earn rewards.

The segment of Domestic workers includes basically those involved with value 'production' for individuals or family frequently, however not exclusively, in a residential setup.

Finally, the segment of Non-paid workers. In fact, this segment of workers does not have a defined function in the context of labor division, in spite of the strong recurrence 
and growth nowadays. It is true to state that non-paid workers may act to help people who are in the condition of employers, selfemployed or workers. However, the most frequent performance has been in the aid of self-employed, in agribusiness or urban activities in precarious situations with the intent to provide for the family.

The brief resume to the central procedures which guided the elaboration of typology of classes was carried out with the purpose to make the reader aware of the systematization of data regarding the structure of positions and class segmentation. Therefore, it is possible to proceed to the empirical approach of the object in analysis in the study.

\section{The occupational structure according to the perspective of positions and segments of social classes in the Metropolitan region of Natal in the 1990s}

Considering the data of Table 1, it can be seen that from 1991 to 2000 there was a small change in the structure of positions of the Employed, Self-employed and workers of the Natal Metropolitan Region. The amount of Employers went from 8,208 to 10,734 people and the relative participation from $2.7 \%$ to $2.8 \%$ of the respective quantitatives in the years of 1991 and 2000. It can be observed that while the number of employers grew on average $3.1 \%$, the average income of this group grew around $7.8 \%$ a year - with the average income going from 11.0 to 21.5 minimum salaries a month. ${ }^{2}$

The amount of Self-employed went from 63,661 to 83,028 people and the relative participation went from $21.0 \%$ to $21.6 \%$. The increase in the number of people was $3.0 \%$ but the average income increased to only $3.6 \%$ a year, that's why the average income went from 2.7 to 3.7 minimum salaries.

Regarding the workers, the contingent went from 231,011 to 291,083 people and the relative participation from $76.3 \%$ to $75.6 \%$. The growth rates during the period went from $2.6 \%$, regarding the amount of people, and only $0.5 \%$ a year regarding the average income, in a way that the latter went from 3.1 to 3.2 minimum salaries a month, approximately. Despite some dynamism in the labor market in this period, it can be seen that there was a relative stability in what concerns the participations of the employers', selfemployed and workers' class positions. On the other hand, there were clear changes in the average income of the three working groups of people. Whereas the average workers' income increased $19.1 \%$ during all the period, regarding the self-employed, there was a $37.2 \%$ increase, and as for the employers it was $95.8 \%$, showing that the great dynamism of the incomes which happened in the labor market of the Metropolitan Region of Natal, comparatively to Rio Grande do Norte and Brazil, had in the Employers the biggest winners.

In order to obtain a more accurate understanding of the class structure during the nineties, the three positions previously mentioned are segmented. The Grand Employers segment remained the same throughout the 1990 s at around 2,030 people. 
Table 1 - Typology of positions and class segments - MANatal (1991 and 2000)

\begin{tabular}{|c|c|c|c|c|c|c|c|c|}
\hline \multirow{3}{*}{ Positions/class segments } & \multicolumn{4}{|c|}{ Employed people } & \multicolumn{2}{|c|}{$\begin{array}{l}\text { Average income } \\
\text { (R\$) }\end{array}$} & \multicolumn{2}{|c|}{ Anual variation (\%) } \\
\hline & \multicolumn{2}{|c|}{1991} & \multicolumn{2}{|c|}{2000} & \multirow{2}{*}{1991} & \multirow{2}{*}{2000} & \multirow{2}{*}{$\begin{array}{l}\text { Employed } \\
\text { people }\end{array}$} & \multirow{2}{*}{$\begin{array}{l}\text { Average } \\
\text { income }\end{array}$} \\
\hline & Quantity & $\%$ & Quantity & $\%$ & & & & \\
\hline Employers & 8.208 & 2,7 & 10.734 & 2,8 & 10,9 & 21,52 & 3,1 & 7,8 \\
\hline Grand employers & 2.031 & 0,7 & 2.028 & 0,5 & 16,93 & 41,33 & $(0,0)$ & 10,5 \\
\hline Small employers more capitalized & 3.995 & 1,3 & 4.453 & 1,2 & 9,44 & 22,85 & 1,2 & 10,4 \\
\hline Small employers less capitalized & 2.183 & 0,7 & 4.254 & 1,1 & 8,28 & 10,68 & 7,8 & 2,9 \\
\hline Self-employed & 63.661 & 21,0 & 83.028 & 21,6 & 2,66 & 3,65 & 3,0 & 3,6 \\
\hline Self-employed in agribusiness & 7.461 & 2,5 & 5.900 & 1,5 & 1,62 & 1,69 & $(2,6)$ & 0,5 \\
\hline Urban self-employed decapitalized & 35.535 & 11,7 & 43.843 & 11,4 & 1,12 & 1,19 & 2,4 & 0,6 \\
\hline Urban self-employed capitalized & 19.621 & 6,5 & 29.544 & 7,7 & 5,17 & 6,15 & 4,7 & 2,0 \\
\hline Self-employed in specialists & 1.044 & 0,3 & 3.742 & 1,0 & 15,26 & 15,84 & 15,4 & 0,4 \\
\hline Workers & 231.011 & 76,3 & 291.083 & 75,6 & 3,05 & 3,19 & 2,6 & 0,5 \\
\hline Workers - directors in the private sector (certified) & 1.456 & 0,5 & 2.214 & 0,6 & 15,52 & 13,33 & 4,8 & $(1,7)$ \\
\hline Workers - directors in the private sector (non-certified) & 6.006 & 2,0 & 5.950 & 1,5 & 5,67 & 5,81 & $(0,1)$ & 0,3 \\
\hline Workers - directors in the public sector (certified) & 1.648 & 0,5 & 1.122 & 0,3 & 13,89 & 17,47 & $(4,2)$ & 2,6 \\
\hline Workers - directors in the private sector (non-certified) & 1.365 & 0,5 & 840 & 0,2 & 6,74 & 8,35 & $(5,3)$ & 2,4 \\
\hline Especialist workers & 9.373 & 3,1 & 12.994 & 3,4 & 13,61 & 14,48 & 3,7 & 0,7 \\
\hline Qualified workers & 16.128 & 5,3 & 32.981 & 8,6 & 5,69 & 5,16 & 8,4 & $(1,1)$ \\
\hline Manual workers in agribusiness & 13.501 & 4,5 & 7.799 & 2,0 & 0,93 & 1,22 & $(6,0)$ & 3,2 \\
\hline Manual workers in industry & 41.673 & 13,8 & 45.254 & 11,8 & 1,75 & 1,69 & 0,9 & $(0,4)$ \\
\hline Manual workers/subaltern tasks in services & 70.876 & 23,4 & 92.098 & 23,9 & 2,15 & 2,14 & 3,0 & $(0,1)$ \\
\hline Non-manual regular workers & 35.268 & 11,6 & 38.085 & 9,9 & 2,69 & 2,71 & 0,9 & 0,1 \\
\hline Non-manual workers more graduated & 8.353 & 2,8 & 13.682 & 3,6 & 5,61 & 4,49 & 5,7 & $(2,5)$ \\
\hline Domestic workers & 23.068 & 7,6 & 30.457 & 7,9 & 0,78 & 1,00 & 3,2 & 2,9 \\
\hline Non-paid workers & 2.298 & 0,8 & 7.607 & 2,0 & - & - & 14,4 & - \\
\hline Total & 302.880 & 100,0 & 384.845 & 100,0 & 3,19 & 3,80 & 2,7 & 2,0 \\
\hline
\end{tabular}

Source: Censo Demográfico, IBGE, 1991 e 2000 (Microdados).

For this reason, their relative participation fluctuated between $0.7 \%$ and $0.5 \%$ from 1991 to 2000. It is necessary to highlight the impossibility of operationalizing the number of grand employers according to the criterion of employment of 100 or more people, as intended, due to limitations in the Census. Therefore, grand employers are represented in the group of those who employed 10 or more people in 1991 and 11 or more people in the year of 2000 . Certainly, there is no doubt about the small share that the segment of grand employers represented of the employed population in the Metropolitan Region of Natal as in the mid-nineties in the research carried out by Santos (2002).

The quantitative permanence of the segment of Grand employers reveals, in a certain way, the existence of "entrance barriers" to this group, the fundamental obstacle being the control of capital assets which translate into rural property, or factories, commercial establishments and the provision of several services. 
As to what concerns the income, it can be noticed that the grand employers constituted the class segment which earned the biggest values in both years, as well as it obtained the biggest increases in the variable during the period. The average income went from nearly 17 in 1991, to a bit more than 41 minimum salaries a month in 2000 , resulting in a growth rate of $10.5 \%$ a year and $144 \%$ in all the period, placing the grand employers as the greatest beneficiaries in the division of the income generated in the metropolitan region of Natal during the nineties. This result was, certainly, due to an economic expansion relatively low, but also to the existence of a big number of unemployed people and a structural excess of workforce in the local aspect, as well as an institutional and political environment which is not propitious to the demands of the workers' class.

It is important to highlight, focusing only on the last year of the period studied (2000), that, in terms of the activity sub-sectors, the biggest relative participation of grand employers occurred in distributive services $(35.7 \%)$ and in the manufacturing industry, civil and heavy construction and utilities (20.4\%), while the lowest frequencies occurred in agriculture $(5.9 \%)$ and in the mining industry (1.1\%). Such data shows that urban activities constituted the privileged locus of wealth accommodation, in the period referred, compared to non-urban activities.

The remaining employers are the small employers most capitalized and the small employers least capitalized. Those who employed 3 to 9 people in 1991 and 3 to 10 in 2000 were considered most capitalized.

And the least capitalized were the ones who employed 1 or 2 people, in both years.
It is clarified that the groups were not strictly the same in both years, due to the way in which the data is organized in the research sources. The idea of segmentation of the small employers had as its aim to separate the employers who don't have the conditions of living exclusively from the work of others who have less need for work, once the capital contribution allows more control over a bigger amount of workers.

The small employers more capitalized had a growth rate relatively low in its contingent, and therefore, lost relative importance, going from $1.3 \%$ in 1991 to $1.2 \%$ of the working people in 2000. On the other hand, the small employers less capitalized had a considerable increase and expanded participation from $0.7 \%$ to $1.1 \%$. As to what concerns the average income, it can be seen that while, in the period, the growth in income for the small capitalized employers was $29 \%$, for the less capitalized it was approximately $142 \%$.

As to what refers to occupations, it can be observed that the Small employers more capitalized were divided into 49 and the Small employers less capitalized into 37 occupational groups. However, $68.4 \%$ of the cases in the first segment occurred in only two groups Company managers (employers who had over 5 employees) and production and operations manager - and $67.4 \%$ of the cases in the second segment in only one group - production and operations manager.

Although the Census data do not allow demonstration, it is reasonable to assume that part of the growth in the number of small employers had occurred due to the privatization of public companies and also volunteer resignation plans in the public sector, enabling minimum capital 
contributions for the beginning of economic activities, in an ideological environment of rising 'entrepreneurship'.

The analysis of the self-employed position is initiated by the segment of the selfemployed specialists or holders of qualified accredited assets. This segment is the one that brings together 'typical liberal professionals', but it also incorporates the holders of technical knowledge which constitute expertise in new economic activities.

The segment of the self-employed specialists was, among all the class segments, the one which had the biggest increase in the number of members during the period of $1991 / 2000$. In this period as a whole, the growth of this contingent was $258.2 \%$ or the equivalent to $15.4 \%$ a year, in a way that the total participation of the working people went from $0.3 \%$ to $1.0 \%$, in other words, although it is a low participation, it is necessary to consider that the expansion in the period was significant. As to what refers to the level of the average income, it is important to highlight that despite the growth throughout the period studied had been very low, its level in the year 1991 was superior to both segments of small employers and in the year 2000 it was even bigger than the one of the segment of small employers less capitalized.

In the year 2000, the participation of occupational groups in the constitution of the Self-employed specialists segment shows that this was integrated mostly by traditional members of liberal professions: Lawyers (23.1\%), Dental-surgeons (17.9\%), Accountants and auditors (15.1\%) and Doctors (11.2\%). It is worth pointing out that the occupational groups connected to more recent economic activities, such as Programming technicians,
System analysts, I.T. programmers and Technicians in computer operation represent altogether $6.1 \%$ of the total participants of the self-employed segments, with more than $70 \%$ of this participation being concentrated in the first group.

Non-holders of accredited qualification assets were initially classified as self-employed non-specialized in rural or urban activities. The Self-employed in agriculture had their number reduced at the rate of $2.6 \%$ per year, one of the worst among the twenty segments, implying a loss of relative position from $2.5 \%$ to $1.5 \%$ in the total occupation. Regarding the average income, an increase of $0.5 \%$ per year was seen, in a way that it reached the level of 1.7 minimum wages in 2000 , giving a clear indication of the precarious situation of the activities carried out by the Self-employed in agriculture. It is important to highlight that, in $2000,71.0 \%$ of the total occupations in this class segment corresponded to the agricultural producers occupational group and $19.7 \%$ to the Fishermen and hunters group, having been the activity groups that occupied the most people in the condition of self-employed in agriculture the following: non-specified agricultural crops (33.6\%), fishing and related services (18.3\%).

The urban self-employed were defined according to the different capital contributions, that is why they were classified as Decapitalized self-employed and Capitalized self-employed. The self-employed with an average income inferior to two monthly minimum salaries were considered decapitalized. This procedure was adopted taking into consideration the fact that if a self-employed earns this much income and has a wife and two kids, the value of the average income per capita will be less than 
$1 / 2$ a minimum salary, which is considered the monetary value that constitutes the 'poverty line' during the period in which the study was conducted. Those who earned an income superior to two minimum salaries were considered capitalized.

Decapitalized self-employed employers and capitalized self-employed had their contingents increased at rates of $2.4 \%$ and $4.7 \%$, respectively, in the $1991 / 2000$ period, which is why the first segment had its share reduced from $11.7 \%$ to $11.4 \%$ and the second increased from $6.5 \%$ to $7.7 \%$ in the years mentioned. Regarding the income of the self-employed workers, it appears that the increases occurred in the period and their average levels also reinforce the precarious situation of the decapitalized and that the largest capital contributions constituted a fundamental condition for the best situation presented by the capitalized.

As to what concerns the occupations, it can be noticed that the decapitalized divided into 133 and the capitalized into 129 occupational groups, respectively. However, $51.1 \%$ of the cases in the first segment are concentrated in only five occupational groups and $57.0 \%$ of cases in the second segment occurred in only seven groups. It is worth pointing out that four occupational groups were common in two segments - Workers in the service of Hygiene and beauty, Vendors and demonstrators in stores or markets, Street vendors and Masonry workers.

Then, the group of workers is analyzed. These are characterized, as a rule, by assuming a position of hierarchical subordination to the employer. However, the structure of occupations performed by workers, an expression of the division of labor at a certain historical moment, implies the constitution of several professional segments. Some segments, as previously mentioned, exercise positions of authority in the institutions in which they operate anchored in organizational assets - power conferred by the exercise of positions or functions based on authority. These positions are exercised by the segments of workers who act as Managers in the private or public sector. As the levels of power exercised by these segments are not homogeneous, workers-managers were segmented according to levels of education to separate those who hold management positions and functions and have accredited qualifications. Higher education holders (those with 15 or more years of study) were considered accredited.

The leading managers of the private sector were initially focused on. Based on Table 1, the occurrence of an increase in the number of accredited private sector managers and a small decrease in the number of private unaccredited sector managers can be seen. The different dynamics made the first segment have its participation elevated from $0.5 \%$ to $0.6 \%$ and the second one reduced from $2.0 \%$ to $1.5 \%$ of the total working people. Concerning the income, a decline in the average income of the accredited managers can be observed at the rate of $1.7 \%$ and the elevation of unaccredited managers' average income at the rate of $0.3 \%$ a year. In spite of such performances, the levels of the income in the year of 2000 reveal that the positions of ruling which were anchored in accredited qualifications were better remunerated than the unaccredited ones. In the year mentioned, while the average income 
of the accredited managers was approximately 13.3, the unaccredited ones was around 5.8 minimum salaries.

The segments of the accredited public sector managers and the unaccredited public sector managers experienced a decrease in their contingent in the period from 1991 to 2000. In the first case, the decrease was at a rate of $4.2 \%$ and in the second one $5.3 \%$ a year. For this reason, they had a loss in relative participation in the labor market members group. Notwithstanding the decrease in their contingents, both class segments experienced an increase in their income, in the case of the accredited managers this increase was superior than the unaccredited ones. Given the fact that readjustments did not integrate the public servants' agenda, during the nineties, especially since the implementation of 'Plano Real', it became evident that only a few segments properly chosen experienced readjustments, in spite of the low rates.

Undoubtedly, power among public sector leaders is concentrated on representatives of the executive, legislative and judiciary powers, military forces officers and leaders of the main public institutions, however, at the end of the period studied, the main groups which concentrate public sector leaders, given the impossibility of presenting the aforementioned occupations separately, were: leaders of the support areas of public administration, leaders of production and operation of the public administration, leaders and managers of organizations of public interest and military from the three forces. First of all, it is worth highlighting that Natal is one of the few state capitals which hosts three military forces. Second, the strong military presence in Natal and Parnamirim consolidated in contemporaneity a trait from the past, the first being called "military city" due to north American and Brazilian military forces spatial interventions from the 1940s to 1950s (Lopes Jr., 2000).

Specialized workers or those with a domain of expert systems represent 3.1\% and $3.4 \%$ of respective total of employed people in 1991 and 2000, due to an average annual growth of $3.7 \%$ of people in the segment. It is also worth mentioning that the average income of the segment in focus was 13.6 and 14.5 minimum wages in the period in question, which points out the social importance given to the accredited qualifications that allow them to work as specialized workers. In 2000, the main occupational groups in the segment of specialized workers was consolidated: higher education professors, programmers, evaluators and teaching advisors, law enforcement officers and the like, doctors, accountants and auditors, and technicians in computer operations.

Qualified workers, or relatively complex workforce, consolidated the segment as the seventh largest contingent of people, in 1991, and the fifth in 2000, having presented one of the highest growth rates, $8.4 \%$ per year, in the period. It is possible to say that the average income followed a trajectory different from the one presented by the number of members. The main occupational groups of skilled workers were: nursing technicians and assistants, school teachers, mechanics responsible for maintenance of motor vehicles, Army military forces and supervisors of administrative services (except for accounting), among others. 
Manual workers in farming consolidated the class segment which experienced the greatest drop in the number of people over the 1990s. For this reason, it was the segment with the greatest change of relative position between 1991 and 2000. Despite such behavior in the number of workers, the segment in focus experienced an average annual increase of $3.2 \%$ in average income. In spite of the performance, in 2000, the segment's income was only 1.22 minimum wage - one of the worst incomes among all class segments, denoting the precariousness of the indicator and the living conditions of the members of the segment.

The number of manual workers in the industry grew at an annual average of $0.9 \%$. Despite the performance, the segment presented, in both years, the second largest number of people, revealing that it is an important class segment in the Metropolitan Region of Natal. It is observed that in this class segment there was a decrease in the average income over the period studied from 1.8 to 1.7 minimum wage. In reality, this information only supports the discussion already undertaken on the restructuring in the industrial sector of the Metropolitan Region which implies a severe on the workforce, especially the proletarianized, which usually faces strong competition from large contingents of workers able to operate in the sector, as well as people who work as outsourced workers. The main groups in the segment were clothing sewing machine operators (15.8\%), masonry structure workers (14.2\%) and construction workers (13.2\%).

The segment of manual workers or in subordinate functions in the services area had its human contingent altered from 70,876 to 92,098 people, implying an increase in the participation in the composition of the occupation from $23.4 \%$ to $23.9 \%$ what keeps the segment to gather the largest number of people among all segments. It is possible to determine that in this class segment the average income remained stagnant for a decade at around 2.1 minimum wages. It should be noted that the proletarian segment consolidated the highest average income in the Metropolitan Region of Natal in the 1990s.

The amount of routine non-manual workers is largely composed by people who work in routine administrative occupations, in occupations that do not require a very high level of training and teachers located at the base of the educational system. In the Metropolitan Region of Natal, the contingent of workers belonging to this class segment was the fourth largest in both years under study. The segment was mainly concentrated in the following occupational groups: high school teachers in elementary school (22.7\%), office secretaries and shorthand writers (15.1\%) and receptionists (12.4\%). The average income of routine non-manual workers was higher than the ones of the three segments of routine manual workers and lower than the ones of skilled workers, as well as the ones of more graduated routine workers, making it clear that the qualifying assets and different hierarchical positions result in the earned income.

The group of more graduated routine non-manual workers presented a high growth rate in the number of people and had a high participation from $2.8 \%$ to $3.6 \%$. In 2000 , it concentrated on the following occupational groups: clerks in general, agents, assistants and administrative assistants (60.9\%), and sales representatives and sales technicians (24.1\%). 
The segment of domestic workers characterized by the 'production' of use values for the family units had important weight for the occupation in the Metropolitan Region of Natal during the 1990s. Its contingent increased from 23,068 to 30,457 people from 1991 to 2000. It is the segment of paid workers with the lowest average income levels, given that, in 1991, it was 0.78, and it reached, in $2000,1.00$ minimum wage, meaning that the annual average increase of $2.9 \%$ only fulfilled the important function of placing workers in the segment in question at the legal minimum wage. Despite being a very low value, it is important to highlight that institutional changes and social pressures were crucial for the average income of the domestic workers segment to reach the level of 1.0 minimum wage in the year in question and the Federal Constitution of 1998, article 7 of Social Rights, item IV, was fulfilled for the "domestic employee" (Brasil, 2006). To reinforce this position, it is important to highlight that in 1980, in the Demographic Census of the same year, the average income of the occupational group "domestic workers" was only $0.4 \%$ minimum wage (Clementino, 1995 , p. 313). I should also be added that only the occupational group Workers in the domestic workers in general was responsible by the occupation of $95.2 \%$ of the total number of people in the segment of domestic workers, but even with much smaller participation, the following occupational groups appeared: kindergarten attendants and elderly caretakers $(2.2 \%)$, cooks $(1.3 \%)$, guards and watchmen $(0.3 \%)$, among others. It is possible to say that the change in housing patterns that has occurred in the Metropolitan Region of Natal since the mid-1980s, characterized by vertical buildings, has induced changes in the nature of domestic work, positions only possible in the context of a demand exercised by social segments relatively high purchasing power and, therefore, with the capacity to enjoy special services at home that have promoted qualitative changes in domestic work in the traditional sense.

Finally, the unpaid workers segment is addressed. The number of people in the non-paid workers segment grew by $231 \%$ in the period, in a way it changed from 2,298 to 7,607 people. Still in 2000 , although the headcount had been distributed to one hundred and twelve occupational groups, only four, admittedly precarious, added approximately half of the occupations: agricultural workers (19.6\%), salespeople and product demonstrators in stores and markets (19.1\%), street hawkers (5.7\%) and waiters, bartenders and butlers (5.4\%).

Finally, it can be determined that, among employers, the control of relatively high capital contributions was essential for participation in the process of appropriating the income created in the Metropolitan Region of Natal in the 1990s. Among the self-employed, the factor that proved to be the most important for participation in the labor market and the income distribution was the possession of qualification assets. The other self-employed people, even those considered capitalized, did not achieve good use in the income distribution in the period highlighted. In the group of workers, in general, the segments that obtained the best results at least in which concerns income levels were those of which the participation in the production process or service rendering was based on accredited qualifications or related to positions which 
involved command or leadership. On the other hand, the segments involved in a precarious nature of work situations, although in some cases having experienced a considerable increase in incomes, in which concerns the levels of these incomes, they remained at the bottom of the distribution. This situation certainly had as a fundamental condition the existence of a political and social environment unfavorable to the workers' claims over the last decade of the 20th century, in the Metropolitan Region of Natal.

\section{Final considerations}

As final considerations, there is a relative 'freeze' in the social classes in the Metropolitan Region of Natal, throughout the 1990s, when taking into account the employers, self-employers and workers. However, when looking at the stratification of the aforementioned alluded positions, it is possible to say that there are random cases of changes in the relative positions of the number of people or even of average incomes. However, it is important to review the watchword represented by the hypothesis: in the context of low dynamism in the economy and in the labor market, the distribution of assets of physical, financial, qualifying and takeover of command positions was decisive for a certain 'freeze' of the class situation in the Metropolitan Region of Natal, where the biggest winners were the big employers, despite the weakness of the source in highlighting them and to a lesser extent the holders of qualifying or organizational assets. The workers deprived of these assets remained immobilized in the base of the class structure.

\section{[I] https://orcid.org/0000-0002-2382-5094}

Universidade Federal do Rio Grande do Norte, Centro de Ciências Sociais Aplicadas, Departamento de Economia. Natal, RN/Brasil.

marconi.br62@gmail.com

Translation: this article was translated from Portuguese to English by Sérgio da Silveira Inácio sergiosiin@gmail.com 


\section{Acknowledgements}

I would like to thank the professors Maria do Livramento M. Clementino and Denílson da Silva Araújo for the contributions given to the production of this paper. However, it is important to point out that I will take full responsibility for any mistakes that have been eventually made

\section{Notes}

(*) It was decided for all the citations to be translated.

(1) The spreading of microdata from Demographic Censuses has been motivating studies on the occupational structure in the metropolitan areas in Brazil with "Observatory of Metropolis" playing an important role in this discussion. For that reason, it is worth mentioning that the "Observatory" developed a social-occupational typology to study large Brazilian urban areas with the microdata from the Demographic Censuses. This social-educational typology is made up of eight groups that are result of the gathering of twenty-four occupational categories, which resulted from occupational groups included in Demographic Censuses.

(2) For a synthetic view of the methodology of typologies of positions and class segmentations used in the study, see the Appendix.

For detailed access of the typologies of positions and class segmentations of 1991 and 2000, check the thesis repository of Universidade Federal do Rio Grande do Norte or send a request to: marconi.br62@gmail.com

\section{Referências}

BRASIL (2006). Constituição da República Federativa do Brasil. Brasília.

BRAVERMAN, H. (1977). Trabalho e capital monopolista. Rio de Janeiro, Zahar.

CLEMENTINO, M. do L. M. (1995). Economia e urbanização: o Rio Grande do Norte nos anos 70. Natal, UFRN/CCHLA.

GIDDENS, A. (1975). A estrutura de classes das sociedades avançadas. Rio de Janeiro, Zahar.

IBGE (1991). Censo Demográfico. (Microdados).

(2000). Censo Demográfico. (Microdados). 
LOPES JÚNIOR, E. (2000). A construção social da cidade do prazer. Natal, EDUFRN.

MAIA, A. G. (2006). Espacialização de classes no Brasil: uma nova dimensão para a análise social. Tese de doutorado. Campinas, Universidade Estadual de Campinas.

MILLS, W. (1979). A nova classe média. Rio de Janeiro, Zahar.

POULANTZAS, N. (1978). As classes sociais no capitalismo de hoje. Rio de Janeiro, Zahar.

QUADROS, W. (2003). Aspectos da crise social no Brasil dos anos oitenta e noventa. Tese de livre docência. Campinas, Universidade Estadual de Campinas.

SANTOS, J. A. F. (2002). Estrutura de posições de classe no Brasil: mapeamento, mudanças e efeitos na renda. Belo Horizonte, Editora da UFMG/Rio de Janeiro, luperj.

SILVA, M. G. da S. (2008). Mercado de trabalho, ocupações e rendimentos: a Região metropolitana de Natal na década de 1990. Tese de doutorado. Natal, Universidade Federal do Rio Grande do Norte.

WRIGHT, E. O. et al. (1989). The debate on classes. Londres, Verso.

(1997). Class counts: comparative studies in classes analysis. Cambridge, Cambridge University Press.

WRIGHT, E. O. (1981). Classe, crise e o Estado. Rio de Janeiro, Zahar.

Received: August 26, 2020

Approved: December 7, 2020 


\section{APPENDIX}

Typology of positions and segmentation of social classes

\begin{tabular}{|c|c|}
\hline $\begin{array}{l}\text { Positions and segmentation } \\
\text { of social classes }\end{array}$ & Methodological criteria \\
\hline 1) Grand employers & $\begin{array}{l}\text { Employers who employed } 10 \text { or more people in their business (1991). } \\
\text { Employers who employed } 11 \text { or more people in their business (2000). }\end{array}$ \\
\hline 2) Small employers more capitalized & $\begin{array}{l}\text { Employers who employed } 3 \text { to } 9 \text { people in their business (1991). } \\
\text { Employers who employed } 3 \text { to } 10 \text { people in their business (2000). }\end{array}$ \\
\hline 3) Small employers less capitalized & $\begin{array}{l}\text { Employers who employed } 1 \text { to } 2 \text { people in their business. The small employers specialists } \\
\text { with low capital (whose occupational groups are part of the specialists segment) were } \\
\text { re-classified as slef-employed specialists. }\end{array}$ \\
\hline 4) Self-employed in agribusiness & Positions in the occupation "independent" in agribusiness activities. \\
\hline $\begin{array}{l}\text { 5) Urban self-employed } \\
\text { decapitalized }\end{array}$ & $\begin{array}{l}\text { Position in the occupation "independent" in non-agribusiness activities. Criterion to } \\
\text { compose the segment: monthly income lower than two minimum wages. }\end{array}$ \\
\hline 6) Urban self-employed capitalized & $\begin{array}{l}\text { Position in the occupation "independent" in non-agribusiness activities. Criterion to } \\
\text { compose the segment: monthly income equal or higher than two minimum wages. }\end{array}$ \\
\hline 7) Self-employed specialists & $\begin{array}{l}\text { Position in the occupation "independent" and with title of specialist or occupational group, } \\
\text { according to categorization of specialist used in the typology. Self-employed specialists with } \\
\text { less than } 15 \text { years of formal education were classified as urban self-employed according to } \\
\text { the income level. }\end{array}$ \\
\hline $\begin{array}{l}\text { 8) Workers - directors in the private } \\
\text { sector (certified) }\end{array}$ & $\begin{array}{l}\text { Employees according to the category of position in occupation; managers or supervisors by } \\
\text { title or occupational group and "employers" performing management tasks in the private } \\
\text { sector. The criterion for classification as certified was } 15 \text { years or more of formal education. }\end{array}$ \\
\hline $\begin{array}{l}\text { 9) Workers - directors in the private } \\
\text { sector (non-certified) }\end{array}$ & $\begin{array}{l}\text { Employees according to the category of position in occupation; managers or supervisors by } \\
\text { title or occupational group and "employers" performing management tasks in the private } \\
\text { sector. The criterion for classification as certified was less than } 15 \text { years of formal education. }\end{array}$ \\
\hline $\begin{array}{l}\text { 10) Workers - directors in the public } \\
\text { sector (certified) }\end{array}$ & $\begin{array}{l}\text { Employees according to the category of position in occupation; managers or supervisors by } \\
\text { title or occupational group and "employers" performing management tasks in the private } \\
\text { sector. The criterion for classification as certified was } 15 \text { years or more of formal education. } \\
\text { Military with less than } 15 \text { years of education were reclassified as qualified workers. }\end{array}$ \\
\hline $\begin{array}{l}\text { 11) Workers - directors in the } \\
\text { private sector (non-certified) }\end{array}$ & $\begin{array}{l}\text { Employers according to the category of position in occupation; managers or supervisors by } \\
\text { title or occupational group and "employers" performing management tasks in the public } \\
\text { sector. The criterion for classification as certified was less than } 15 \text { years of formal education. }\end{array}$ \\
\hline 12) Specialist workers & $\begin{array}{l}\text { Employees according to the category of position; specialists by title or occupational group, } \\
\text { notably those who hold certified positions and possess scarce knowledge or qualifications } \\
\text { about the systems of technical expertise or professional skill. More than eleven years } \\
\text { or more of education (criterion of "filter" to exclude conflicting cases classified in the } \\
\text { occupational groups). }\end{array}$ \\
\hline 13) Qualified workers & $\begin{array}{l}\text { Employees as in the occupational position, qualified workers according to the title or } \\
\text { occupational group, notably hand workers, 5th to 8th grade teachers, high school teachers, } \\
\text { technicians and those with education level of high school, intermediate or semi-professional } \\
\text { with rare knowledge or skills. They have five years or more of education (criterion of "filter" } \\
\text { to exclude conflicting cases classified in the occupational groups). } \\
\text { Inclusion of cases of classification of specialists by title or occupational group that were } \\
\text { "filtered" due to the fact that they had } 10 \text { years or less years of education. }\end{array}$ \\
\hline 14) Manual workers in agribusiness & $\begin{array}{l}\text { Employees according to the position in the occupation and manual workers in agribusiness } \\
\text { according to title or occupational group. }\end{array}$ \\
\hline 15) Manual workers in industry & $\begin{array}{l}\text { Employee according to the position in the occupation and manual workers in non- } \\
\text { agribusiness activity according to title or occupational group. }\end{array}$ \\
\hline $\begin{array}{l}\text { 16) Manual workers or in service } \\
\text { subaltern tasks }\end{array}$ & $\begin{array}{l}\text { Employee according to the position in the occupation and manual workers in non- } \\
\text { agribusiness activity according to title or occupational group. }\end{array}$ \\
\hline
\end{tabular}




\begin{tabular}{|l|l|}
\hline 17) Regular non-manual workers & $\begin{array}{l}\text { Employee according to the position in the occupation and non-manual regular workers } \\
\text { according to title or occupational group. } \\
\text { Inclusion of conflicting cases of classification of qualified workers by title or occupational } \\
\text { group that were "filtered" due to the fact that they had } 4 \text { years or less years of education } \\
\text { and whose work profile is close to the occupational category. }\end{array}$ \\
\hline $\begin{array}{l}\text { 18) More graduated non-manual } \\
\text { workers }\end{array}$ & $\begin{array}{l}\text { Employee according to the position in the occupation and non-manual worker according to } \\
\text { title or occupational group (in terms of professional degree/qualification, execution of tasks } \\
\text { delegated by the employer, perception of rewards for performance or normal tasks for the } \\
\text { occupation and institutional conditions linked to the public sector of employment. }\end{array}$ \\
\hline 19) Domestic workers & Domestic workers by position in the occupation and title or occupational group. \\
\hline 20) Non-paid workers & People who were working to help Family members. \\
\hline
\end{tabular}

Source: typology based on Santos (2002). 
